\title{
Gap between Humidity Cell Testing Data and Geochemical Modeling of Acid Rock Drainage
}

\section{Surya P. Sunkavalli*}

Environmental Geochemist, Geomega Inc, 2525 28th street, Boulder, Colorado-80503, Colorado, USA

Rock Piles are man-made structures consisting of piles of non-ore overburden material that had to be removed in order to extract ore. These materials were discarded by dumping in rock piles as close to the open pit. In the long run they became the reason for environmental hazards. They pose problems like acid rock drainage (ARD), leaching of heavy metals, erosion, slope stability concerns, and undesirable aesthetic views. ARD is a major source of water pollution arising from the weathering of sulfide bearing minerals. The formation of acid drainage and the contaminants associated with it have been described by some as the largest environmental problem facing the U.S. mining industry [1].

Weathering is a complicated process, but under certain assumptions, it can be simulated in chemical, physical and geological terms to help predict geochemical changes. Thus, modeling is an important tool in the management of mining rock piles since it is one of the few methods that can give a quantitative estimate of the chemistry and physical property changes occurring over long weathering time periods. There have been numerous mathematical models of weathering and ARD over the last few decades, starting with rather simple models to very complicated coupled models [2-5]. The problem is that ARD is a very complex process involving not only mineralogical and geochemical changes but physical and biological changes as well. Most rock piles are heterogeneous in terms of mineralogy and flow properties and the ARD process involves all three phases - solid, liquid and gas.

Normally Humidity cell tests (HCT) are used to predict the timing and extent of acid rock drainage. However, these tests can also be used to determine the governing intrinsic geochemical kinetic parameters that are involved in the development of acid rock drainage for that particular rock sample. Once kinetic parameters are obtained from humidity cell testing through simulation and calibration, these parameters can be used in a geochemical model that simulates the natural environment in an actual rock pile. An ASTM standard humidity cell testing procedure was published in 1996 and then updated several times [6,7] .
One of the biggest challenges currently faced by environmental practitioners is how to use site-specific data, such as HCTs, in predictive geochemical models. The extrapolation of Lab data to field level is not well defined. Not much literature available on coupling HCT data to the field geochemical modeling. Most of the geochemical modeling was done by some sort of scaling to the HCT kinetics. Sapsford and Williams 2005 [8] mentioned that humidity cells represent a different leaching environment than that in the field and so direct scaling-up of results by weight correction will give erroneous results.So there is an urgent need of research on methodology for incorporating humidity cell testing data in prediction of field scale geochemical models.

\section{References}

1. Lapakko KA (1993) Mine Waste Drainage Quality Prediction: A Literature Review. Minnesota Department of Natural Resources, Division of Minerals: St. Paul, MN.

2. Sunkavalli S, Kidder J, Heatwole K, Shier D, Davis A (2013) WROC - An improved waste rock oxidation code. Minerals \& Metallurgical Processing 30: 169-173.

3. Lefebvre R (1995) Modeling Acid Mine Drainage in waste rock dumps. In TOUGH Workshop, Berkeley, CA, USA

4. Niewiadomski M, Trujillo E, Li Y, Sunkavalli $S$ (2009) Modeling acid rock drainage in a mine rock pile using a modified version of TOUGHREACT. In TOUGH Symposium. Lawrence Berkeley National Laboratory, Berkeley, California, USA.

5. Parkhurst DL, Appelo CAJ (1999) User's guide to PHREEQC (Version 2) A computer program for speciation, batch-reaction, one-dimensional transport, and inverse geochemical calculations. US Geological Survey.

6. ASTM (2007) Standard Test Method for Laboratory Weathering of Solid Materials Using a Humidity Cell. D5744-07: 1-19.

7. ASTM (2001) Standard test method for accelerated weathering of solid materials using a modified Humidity Cell. D 5744-96.

8. Sapsford DJ, Williams KP (2005) Predominant chemical kinetics in laboratory prediction of ARD. in 9th International Mine Water Congress.
*Corresponding author: Surya $\mathrm{P}$ Sunkavalli, Environmental Geochemist, Geomega Inc, 2525 28th street, Boulder, Colorado-80503, Colorado, USA, Tel: 801-574-0865; E-mail: spsuryaprakash@yahoo.com

Received January 05, 2014; Accepted January 06, 2014; Published January 10, 2014

Citation: Sunkavalli SP (2014) Gap between Humidity Cell Testing Data and Geochemical Modeling of Acid Rock Drainage. Hydrol Current Res 5: e115. doi:10.4172/2157-7587.1000e115

Copyright: ( 2014 Sunkavalli SP. This is an open-access article distributed unde the terms of the Creative Commons Attribution License, which permits unrestricted use, distribution, and reproduction in any medium, provided the original author and source are credited. 